\title{
Az endoszkópia és gasztroenterológia szerepe, múltja, jelene és jövője a Semmelweis Egyetem I. sz. Sebészeti Klinikáján
}

\author{
HRITZ ISTVÁN, SZIJÁRTÓ ATTILA
}

Semmelweis Egyetem, I. sz. Sebészeti Klinika, Budapest

\begin{abstract}
Az emésztőszervi endoszkópia mint a belgyógyászati gasztroenterológia és a gasztroenterológiai sebészet régóta nélkülözhetetlen kiegészítője, mára lényegében különálló határdiszciplínává vált. Az endoszkópos vizsgálatok, a hagyományos diagnosztikus és szürő jellegü endoszkópia keretein túl, manapság kiemelt szerepet játszanak a tápcsatornai megbetegedések kezelésében és palliációjában.

$\mathrm{Az}$ emésztőszervi endoszkópia (kezdetekben merev, majd flexibilis eszközökkel) korábban szinte kizárólag csak a diagnosztika részeként volt számon tartva. A múlt század végén azonban ugrásszerủen nőttek az endoszkópia operatív lehetőségei, mígnem napjainkban egyes módszerek szinte kizárólag operatív metodikákká váltak. Az elmúlt években átalakult nemcsak az endoszkóposok, hanem a társszakmák szemlélete is, jelenleg elvárás, hogy egy-egy centrumban magas szakmai felkészültséget igénylő, a korábbiaknál magasabb rizikót, ám a beteg számára sokkal kevésbé megterhelő, invazív endoszkópos beavatkozásokat, intervenciókat végezzenek.
\end{abstract}

A Semmelweis Egyetem I. sz. Sebészeti Klinikán a gasztroenterológiával való szoros együttmüködés és az endoszkópos jártasságok megszerzése, valamint azok széles tárházának alkalmazása történelmi jelentőséggel bír. Egyes - a diagnosztikus elemektől a kezelésig terjedő beavatkozások hazai megjelenése, bevezetése, protokollok kidolgozása a Klinikához köthető (pl.: nyelöcső-scleroterápia, palliatív nyelöcsö-endoprotézisbeültetés, percutan endoszkópos gastrostomia, endoszkópos/ultrahangvezérelt hasnyálmirigy pseudocysta-szájaztatás).

A nyelőcsővarix-vérzés endoszkópos kezelése Magyarországon, nemzetközi összehasonlításban igen korán, elöször az I. sz. Sebészeti Klinikán került bevezetésre. Úttörője Kupcsulik Péter volt, aki Németországban szerzett tapasztalatait alkalmazta a klinikai gyakorlatban. A nyelöcsővarixok endoszkópos scleroterápiája a Klinikán 1980-tól pár évig még merev eszközzel, majd később flexibilis endoszkóppal történt. 1980 és 1990 között, lényegében folyamatos ügyeleti rendszerben, szinte kizárólag a Klinika látta el az akut felső tápcsatornai vérző betegeket. A vizsgálatok túlnyomó részét Kupcsulik Péter és Kokas Péter sebészek, valamint Éles Zsuzsa belgyógyász végezték. A folyamatos továbbképző tanfolyamoknak és előadásoknak köszönhetően az endoszkópos vérzéscsillapítás módszer országszerte el tudott terjedni. ${ }^{1}$
A 1990-es években és az ezredfordulót követő időszakban is (2017-ig bezáróan) az egyetemen a tápcsatornai vérzés ellátása az I. sz. Sebészeti Klinikán történt, Lukovich Péter és Szijártó Attila sebészek, valamint Wacha Judit és Takáts Alajos belgyógyászok bevonásával. 2017 óta az urgens tápcsatornai endoszkópiát igénylő betegek endoszkópos ellátását az egyetem klinikáin (beleértve az I. sz. Sebészeti Klinikát) dolgozó gasztroenterológus szakorvosok és szakasszisztensek végzik állandó készenléti rendszerben, központosítva, a Sürgősségi Betegellátó Osztály aktív közremüködésével.

A palliatív célú nyelöcsőendoprotézis-beültetés módszere 1979 óta ismert. A rigid protéziseket a 2000-es években megjelent és gyorsan elterjedő öntáguló fémstentek váltották fel. A történelmileg is erős felső tápcsatornai sebészeti profilnak köszönhetően a Klinikán napjainkban is nagyszámú nyelöcsőrákos beteg kezelése történik. A kuratív sebészeti megoldások mellett a palliatív nyelőcső beavatkozásokban is úttörö szerepe van a Klinikának. ${ }^{2} 1984$ és 2019 között a Klinikán 1223 betegnél történt endoprotézis-beültetés, 844 esetben ún. „rigid tubus”, 379 esetben öntáguló fémstent (SEMS) került beültetésre. ${ }^{3} \mathrm{Az}$ endoprotézis beültetések zömét Kupcsulik Péter és Balázs Ákos végezte, napjainkban Vass Tamás végez egyre több SEMSimplantációt.

A táplálkozásra képtelen betegek tartós enteralis táplálása percutan endoscopos gastrostomia $(\mathrm{PEG})$ révén biztosítható. Magyarországi honosítása 1990-ben, Harsányi László és Bodoky György révén, az I. sz. Sebészeti Klinika égisze alatt történt. ${ }^{4} \mathrm{Az}$ eredeti Gauderer-technika módosítása, a transnasalis endoszkópos technika és az intraoperatív PEG-beültetés is közvetve a Klinikához köthető. ${ }^{5}$ Napjainkban az egyetemen a legtöbb PEG-implantáció Klinikánkon történik, évi kb. 100-200 esetben. A betegek zöme a Fül-Orr-Gégészeti és Fej-Nyaksebészeti Klinikáról, a Neurológiai Klinikáról és az Országos Orvosi Rehabilitációs Intézetből érkezik.

$\mathrm{Az}$ endoszkópos modalitások hazai innovációjában a Klinika mindig elöl járt. Az 1990-es években, Magyarországon elsőként, konvex (lineáris) echoendoszkóp került beszerzésre, amely a tápcsatorna fali rétegeinek képi megjelenítése és a szomszédos képletek és szervek részletdús ábrázolása mellett, már a munkacsatornán keresztül bevezetett finomtü aspirációs mintavételre is lehetőséget adott. 
Az első hazai tapasztalatokról közlemény formájában Winternitz Tamás számolt be. ${ }^{6}$

Az ezredforduló után a lendület megtört, számottevő újítás a Klinika endoszkópos laborjában, főleg anyagi források hiányában nem valósult meg, hangsúly főként a sebészeti betegek endoszkópos követésén és szürésén, valamint a funkcionális vizsgálatokon volt, komoly intervenció, progresszív endoszkópia nem nagyon volt terítéken.

2017-ben a Klinika elöregedett endoszkópos eszközparkja megújult, a személyi állomány frissülésével (orvos, asszisztens) az endoszkópos mühely új lendületet kapott. Az Invazív Endoszkópos Centrum megalakulásával az I. sz. Sebészeti Klinika az egyetem fó és egyetlen teljes spektrumú intervenciós endoszkópos ellátó helyévé vált, a kiemelt progresszivitási országos, területi és belső egyetemi igényeknek eleget téve.

2018-2019-ben újabb humán erőforrás-frissüléseknek köszönhetően az egyre bővülő intervenciós és palliatív (felső és alsó tápcsatorna, pancreato-biliaris rendszer) beavatkozások mellett a gyulladásos bélbetegségekkel küzdő nehéz beteganyag komplex (konzervatív és sebészi) kezelésére és endoszkópos követésére, szürésére is lehetőség nyílt.

2019 közepétől három gasztroenterológus-endoszkópos szakember (Horváth Miklós, Miheller Pál és Hritz István), valamint endoszkopizáló sebészek (Bencze Viktória, Kupcsulik Péter, Kokas Péter, Vass Tamás és Ferreira Gábor), szakmai érdeklődésüknek megfelelően végzik a vizsgálatokat, négy endoszkópos szakasszisztens hathatós segítségével.

A diagnosztikus, szürő- és követővizsgálatok mellett a tápcsatornai rákmegelőző elváltozások teljes egészében történő eltávolítása (polypectomia, endoscopos mucosa resectio, endoscopos submucosus dissectio), valamint a sebészileg inoperábilisnak minősült elváltozások palliációja (pl. endoszkópos tágítás, öntáguló nyelőcső, duodenumés vastagbélfémstent-implantatio) elérhető és alkalmazott technikák Klinikánkon. A manapság szinte kizárólag csak operatív célokra alkalmazott epeúti endoszkópos eljárást, az endoszkópos retrográd cholangio-pancreatographiát (ERCP), amely során többek között lehetőség van az epeúti kövek eltávolítására, az epe- és a pancreas vezeték cytológiás mintavételére, az epe- és hasnyálmirigynedv elfolyásának biztosítására, valamint a szükületek tágítására, napi rutinban végezzük. A bilio-pancreaticus-megbetegedések diagnosztikájában és stagingjében alkalmazott arany-standard vizsgálómódszer, az endoszkópos ultrahang (EUH), a részletdús szerkezeti megjelenítés és a célzott szöveti mintavétel lehetősége révén (finomtü-aspiráció) kiemelkedő jelentőséggel bír, mindemellett a Magyarországon csak néhány centrumban elérhető, olyan minimálisan invazív operatív beavatkozás is elvégezhető központunkban, amely során az endoszkópos képet ötvözzük az ultrahangos és röntgen-képalkotással - ún. EUH-vezérelt transluminalis intervenció (pl. cystogastrostomia, epeúti drenázs, pancreas-necrosectomia, plexus coeliacus neurolysis, tumorablatio). Az EUH licenchez szükséges komplex oktatás és vizsgáztatás, a grémiumi rendszer keretei között, Klinikánkon történik.

Mindezek a napi gyakorlatban alkalmazott endoszkópos modalitások szervesen illeszkednek a Klinika égisze alatt müködő hepato-pancreato-biliaris kutatási centrum (HPB Research Center) munkájába.

2020 őszétől a szakmai profiltisztításnak köszönhetően az I. sz. Sebészeti Klinikán alakul meg az egyetem gasztroenterológiai részlege, melynek szerves része a felújított Invazív Endoszkópos Centrum. A korábbi II. sz. Belgyógyászati Klinikán müködő gasztroenterológiai munkacsoportban dolgozó gasztroenterológusok és az endoszkópos szakasszisztensek nagy többsége csatlakozik az új részleghez, ahol az újonnan létrehozott 30 ágyas fekvőbeteg osztály mellett összesen hat endoszkópos vizsgáló került kialakításra, melyek közül kettőben fluoroscopiás egység is helyet foglal. Az eszköz- és tartozékpark bővül, a meglévő vizsgáló modalitásokat a kapszulaendoszkópia fogja kiegészíteni.

Az I. sz. Sebészeti Klinika endoszkópos laborjának megújításával, a megalakuló gasztroenterológiai részleg mellett, az Invazív Endoszkópos Centrum kiépítésével célunk - megfelelő keretek között - egy aktív müködési rendszer megteremtése, a betegellátás, oktatás és kutatás egyetemi egység minőségi égiszének megfelelően.

\section{Irodalomjegyzék}

${ }^{1}$ Kupcsulik P: Az Üllői úti Sebészeti Klinika 1909-2009. Semmelweis Kiadó 2009; 87-89.

${ }^{2}$ Kupcsulik P, Balázs Á, Miklós I, Kokas P: Inoperabilis nyelőcsődaganatok palliatív kezelése endoszkópos tubuslevezetéssel. Magy Onkol 1990; 34: 155-164.

${ }^{3}$ Balázs Á: Malignus nyelőcsőszűkületek kezelése endoprotezis beültetéssel. GlobeEdit Mauritius 2019.

${ }^{4}$ Harsányi L: Balassa Emlékelőadás 2019. Sebészet és innováció. Magyar Sebészet 2020; 73(1): 3-15.

${ }^{5}$ Taller A, Horváth E, Iliás L, Kótai Zs, Simig M, Elö J, Harsányi L: Technical modifications for improving the success rate of PEG tube placement in patients with head and neck cancer. Gastrointest Endosc 2001; 54(5): 633636.

${ }^{6}$ Winternitz T, Kokas P, Éles Zs, Kupcsulik P, Döngölö L, Flautner L: Gastroenterologic endoscopic ultrasonic examinations using a convex transducer. Orv Hetil 1997; 138(2): 75-79.

A cikk a Creative Commons Attribution 4.0 International License (https://creativecommons.org/licenses/by/4.0/) feltételei szerint publikált Open Access közlemény, melynek szellemében a cikk bármilyen médiumban szabadon felhasználható, megosztható és újraközölhető, feltéve, hogy az eredeti szerző és a közlés helye, illetve a CC License linkje és az esetlegesen végrehajtott módosítások feltüntetésre kerülnek. (SID_1) 